\title{
THE IMPACT OF MAIZE-BASED ETHANOL PRODUCTION ON THE COMPETITIVENESS OF THE SOUTH AFRICAN ANIMAL FEED INDUSTRY'
}

\author{
D.B. Strydom², F. Meyer ${ }^{3}$, P.R. Taljaard ${ }^{4}$ and B.J. Willemse ${ }^{5}$
}

\section{ABSTRACT}

Over the past few years the world has witnessed substantial developments in the global production and the production capacity of ethanol. This tremendous growth in the industry is mainly driven by the following: petroleum prices, the reliability of traditional crude oil exporters along with political motives, adverse pollution effects and more specifically, emission gases from fossil fuels. Together with this growth, various researchers locally and globally have focused on ethanol production, but little work has been done on the economic impact that ethanol production will have on the animal feed industry. In order to simulate the results, the two main scenarios were analysed using two different models - namely, the BFAP model and the APR model. By applying the BFAP model to these scenarios, the equilibrium prices of animal feed raw materials were simulated for the year 2015. The APR model was then applied to these prices in order to evaluate the impact of ethanol production on the animal feed industry. Two main scenarios are constructed with four combinations; the main variables in the scenarios are the oil price and the blending ratios of biofuel. The results revealed that there is no significant effect on the animal feed industry. Various raw materials are affected, but only by small percentages. The only raw material that shows any significant change is lucerne, with a 20 per cent decrease in consumption. The greatest effect is the replacement of imported protein raw materials by DDGS (dried distillers grains with solubles). In terms of the animal feed costs, there was only a 2 per cent decrease with the introduction of ethanol production. Under a scenario of high blending ratios and oil prices, the yellow maize price increases by $\mathrm{R} 169 /$ ton and the soya oilcake price decreases by R347/ton.

Keywords: ethanol, maize, DDGS, animal feed

\section{$1 \quad$ INTRODUCTION AND BACKGROUND}

Globally, biofuels are becoming an increasingly important source of energy. The international biofuels industry experiences tremendous growth, mainly driven by the following: increased energy and more specifically, petroleum prices, reliability of traditional crude oil exporters along with political motives, adverse pollution effects (methyl tertiary butyl ether - MTBE) and more specifically, emission gases from fossil fuels, leading to global warming with increased social pressure for the use of cleaner burning fuels to save the environment. Two basic biofuels are 
produced across the world: biodiesel and bioethanol (Wiesner 2006). According to RFA (2007), in 2007 the US was the largest producer with 183, 7 billion litres of ethanol produced annually, followed by Brazil with 170 billions litres, while the EU and US are the main biodiesel producers, with the EU producing 64 billion litres of the global biodiesel (mainly from rapeseed) while the US produced 26 billion litres (mainly from soya beans). According to Trenkle (2008) global ethanol and biodiesel production increased by 309 per cent and 73 per cent respectively from 2004 to 2007, and a further 57 per cent and 73 per cent are forecast from 2007 to 2012 for ethanol and biodiesel respectively. For the purpose of this study, the focus falls on ethanol, which can be produced from feedstock such as cassava, coarse grains (maize, sorghum and wheat), sugar cane, sugar beet, biomass (material of recent biological origin that can be used either as a source of energy or for its chemical components) and small grains (Albers 2006).

When producing ethanol, the by-product of Distillers Grains with Solubles (DGS), which is rich in protein, can be used in animal feed rations (Dunn 2005). If this by-product is dried, a product - namely, Dried Distillers Grains with Solubles (DDGS) is produced. As a result of the increase in the production of ethanol, there has been a vast increase in the supply of DDGS in the USA. According to the USDA (2007), the US is currently a surplus producer of DDGS, and it is becoming a problem because of the surplus resulting from export and storage difficulties, as well as the fact that DGS in a wet form is expensive to transport and to dry. A large amount of DDGS is also currently wasted due to its surplus production. DDGS can be a substitute for numerous protein-rich raw materials such as oilcakes in animal feed rations, which results in price reactions.

Currently, biofuels are not yet a reality in South Africa - mainly because of barriers to entry such as high feedstock prices and in particular, the delayed biofuels industrial strategy. The first draft of the Government Biofuels Industrial strategy, developed by the Department of Minerals and Energy (DME), was released for comment in December 2006. According to the DME (2007), various stakeholders declared that the draft had a few misinterpretations and failed to cover the effects on agriculture adequately. Consequently, the draft was withdrawn for reconsideration after comments from stakeholders, and a new draft was approved by Cabinet in December 2007.

"This draft document presents the proposed South African Biofuels Industrial Strategy and outlines Government's approach to policy, regulations and incentives" (DME 2007). According to the DME (2007) the draft was developed in order to focus on creating jobs in the energy-crop and biofuels value chain, and to act as a bridge between the first and second economy. According to the DME (2007), the target is to achieve a 2 per cent penetration level of biofuels in the national liquid fuel supply by 2013 , which amounts to 400 million litres of biofuels to be blended 
into normal fossil fuels at blending ratios of 2 per cent biodiese $\left(\mathrm{B}_{2}\right)$ and 8 per cent ethanol $\left(\mathrm{E}_{8}\right)$ at current consumption levels. According to the DME (2007), the 2 per cent level can be achieved without jeopardizing food security.

In order to reach this target, 1.4 per cent of arable land in South Africa is needed, which must come from former homelands (including Bophuthatswana, Ciskei, GaZankulu, KaNgwane, KwaZulu, Lebowa, Qwaqwa, Transkei and Venda). Currently, 14 per cent of arable land, mainly in the former homelands, is underutilized (DME 2007). According to the DME (2007), in terms of the first and second economy trajectory, Government will have to support the development of the under-utilized land to a level that will enable it to compete commercially. These farmers will be encouraged to participate in the biofuel refineries through cooperatives.

The main objective of this study is to investigate the impact of compulsory biofuel blending ratio policies on the animal feed industry if the strategy is implemented. This will be undertaken by making use of a base scenario that incorporates a combination of key drivers and uncertainties within the modelling framework. This will be followed by a sensitivity analysis to test the impact of high crude oil prices on the animal feed industry. In the remainder of this article, section 2 provides the problem statement, followed by section 3 with a description of the methodology and data. The simulated results are discussed in section 4, followed by conclusion and recommendations.

\section{PROBLEM STATEMENT}

Ethanol production is likely to have an impact on the animal feed industry - mainly because of the introduction of ethanol production by-products suitable as animal feed, as well as the impact of biofuel production on feed grain prices, which will have possible effects on the industry's competitiveness. The by-product distillers grains with solubles - known as dried distillers grains with solubles (DDGS) when dried - is a protein-rich raw material, and when balanced into animal feed is likely to lead to changes in commodity prices, changes in the consumption of different animal feed raw materials, and changes in feed costs, mainly because it would be a substitute for imported protein-rich raw materials currently used in animal feed. If maize is used as a feedstock in ethanol production, this means that maize supply would decrease in the feed industry, with subsequent effects on the animal feed industry.

Globally, various researchers have studied the economic effects of biofuel production. Authors such as Banse, Van Meijl, Tabeau and Woltjer (2007); Dixon, Osborne and Rimmer (2007); Reilly and Paltsev (2007); Birur, Hertel and Tyner (2008); and Hertel, Tyner and Birur (2008) argue that since biofuels are mostly produced from agricultural commodities, their effects are largely felt in agricultural 
markets with major land use. Almost all of these articles have over-emphasised the impact of biofuels on agricultural markets due to the fact that they ignore the role of by-products resulting from the production of biofuels. Authors who have addressed DDGS are Tokgoz, Elobeid, Fabiosa, Hayes, Babcock, Yu, Dong, Hart and Beghin (2007); Babcock (2008); and Tyner and Taheripour (2008), but they only quantified the impact of bio-fuel production on agricultural markets, and not on sectors within the agricultural sector. This means that they only looked at effects such as land use and commodity yields.

In South Africa biofuel research projects mainly focus on feasibility studies. Lemmer (2006), for instance, investigated the impact of wheat-based ethanol production in the Western Cape Province, while Albers (2006) examined the feasibility of maize-based ethanol production in South Africa, and the Department of Minerals and Energy (DME 2006) investigated the feasibility of biodiesel and ethanol production with various feedstocks.

The problem with these studies is that they present the effects of DGS as a by-product in terms of the quantities that would be produced and the possible substitution of protein raw materials, for example, but they do not mention the actual effects within the animal-feed industry. Albers (2006) touched on the impact, but under the assumption of foreign ethanol production figures, and did not include an in-depth analysis of changes within the animal feed industry. Another shortcoming with the analysis of Albers (2006) is that no price shifts were taken into account, thus rendering the data static. Dunn (2005) conducted a more in-depth study on the impact of DDGS, but with the same shortcoming as Albers (2006) - namely, that he did not use equilibrium prices. Dunn (2005) used different prices with different scenarios, but did not use a specific equilibrium price and did not take into account that other commodities would also be subject to price changes. The Bureau for Food and Agricultural Policy (BFAP) team also conducted three reports. In all the three reports, BFAP (2005), BFAP (2007) and BFAP (2008), a study similar to this thesis was done, but these reports had shortcomings in that fixed aggregate feed rations were used and only the net effects on the various feed grains were illustrated. The benefit of these reports is that equilibrium prices were simulated dynamically.

In the light of the literature referred to above, there is a need to quantify the impact of maize-based ethanol production on the South African animal feed industry in a state where prices are in equilibrium. It is important to know the possible impact that the introduction of DDGS would have - mainly because it could affect policy and trade decisions, as well as competitiveness. It is important to determine the effects of this new protein source and how it would impact and compete with other raw materials in the animal feed industry. The introduction of DDGS could reduce protein imports, because currently South Africa is a net 
importer of protein (AFMA 2007). The results of this article could help experts to adjust their animal feed rations and also keep their stakeholders informed as to what they can expect within various feed sectors.

In order to quantify the impact, two models were used. The first model is the BFAP model. The BFAP model projects a set of equilibrium prices for 2015 under a specific set of assumptions. These equilibrium prices are incorporated into the Agricultural Product Requirement (APR) model, where the changes in animal feed consumption are quantified. The remainder of this section provides an indepth explanation of the models and methods used to generate results.

\subsection{The BFAP model: Scenario 1}

The BFAP model was used to estimate the raw material equilibrium prices for 2015. The BFAP sector model is a dynamic system of econometric equations, which has the ability to model cross-commodity linkages (Meyer et al. 2007). A set of equilibrium prices is generated by the BFAP sector model under the scenario explained below, whereafter the equilibrium prices are used in the APR model. A number of underlying drivers and uncertainties in the scenario were developed for the purpose of this study.

Drivers are factors or a combination of factors of which the direction of change, magnitude of change, as well as the impact of change, are predictable. The following drivers were used to develop a scenario: legislation, population, urbanization, disposable income, local profitability of the production of protein, biofuels, oilseed markets, the crude oil market, as well as the exchange rate (macro economy). These drivers, which could impact on the animal feed industry are explained in more detail in Table 1.

A key uncertainty is a factor or combination of factors of which the direction, magnitude and impact of change are totally unpredictable. The following uncertainties are identified in order to develop the scenario: biofuels, legislation, crude oil, lack of electricity supply, macro economic shocks in the USA, EU, China and Japan. The likely effects of the uncertainties are explained in more detail in Table 2. 
Table 1: Drivers scenario 1 (2007 - 2015)

\begin{tabular}{|c|c|}
\hline Driver & Effect \\
\hline \multirow[t]{4}{*}{ Legislation } & Balance between government policies on job creation vs food inflation \\
\hline & $\begin{array}{l}\text { DTI (Dept of Trade and Industry) and NDA (National Dept of } \\
\text { Agriculture), main Government institutions determine Government } \\
\text { policy that affects agriculture. }\end{array}$ \\
\hline & Import tariffs on all meats remain in place. \\
\hline & Land reform will continue at a slow pace. \\
\hline \multirow[t]{2}{*}{ Population } & $\begin{array}{l}\text { Continuation of legal and illegal immigrants with a small positive growth } \\
\text { rate of local population causes population to grow. }\end{array}$ \\
\hline & $\begin{array}{l}\text { The impact of HIV/ AIDS is smaller than anticipated due to the effective } \\
\text { use of antiretroviral drugs. }\end{array}$ \\
\hline \multirow[t]{3}{*}{ Urbanisation } & $\begin{array}{l}\text { Urban areas are associated with a higher level of income. Driving the } \\
\text { food consumer to more value added goods. }\end{array}$ \\
\hline & $\begin{array}{l}\text { The presence of urbanisation is expected - starchy staples change to } \\
\text { more value added goods. }\end{array}$ \\
\hline & Urbanisation has a dampening effect on the growth of the population. \\
\hline \multirow[t]{3}{*}{ Disposable income } & Slow pace of job creation will continue. \\
\hline & Expenditure patterns of black middle income vs "fat cats" can shift. \\
\hline & $\begin{array}{l}\text { New credit laws \& higher interest rates will not affect the consumption } \\
\text { of basic food items negatively. }\end{array}$ \\
\hline \multirow{4}{*}{$\begin{array}{l}\text { Profitability of protein } \\
\text { production }\end{array}$} & Maize and soya price ratio is critical. \\
\hline & Yields maize vs soya increases. Both continue past trends. \\
\hline & The oil fraction of soya beans remains constant. \\
\hline & $\begin{array}{l}\text { Rebate of the duty on soya beans for the extraction of soya bean oil to } \\
\text { be used in the production of biodiesel is in place. }\end{array}$ \\
\hline \multirow[t]{4}{*}{ Biofuels } & Government commitment to meet Kyoto Protocol. \\
\hline & $\begin{array}{l}\text { Biofuels "drop in the bucket" of global energy market, huge impact on } \\
\text { agricultural commodities. }\end{array}$ \\
\hline & $\begin{array}{l}\text { Biofuels in SA will not have a positive impact on the labour market, } \\
\text { which Government is hoping for. }\end{array}$ \\
\hline & $\begin{array}{l}\text { Technical constraints of blending ethanol into petrol are not experienced } \\
\text { when blending biodiesel into diesel. }\end{array}$ \\
\hline \multirow[t]{2}{*}{ Oilseed market } & World demand for oilseeds will continue to outstrip supply. \\
\hline & $\begin{array}{l}\text { Expansion of soya bean crushing facilities will remain, and soya beans will } \\
\text { trade closer to import parity levels. }\end{array}$ \\
\hline Crude oil market & $\begin{array}{l}\text { Political instability in the Middle East will keep on putting upward } \\
\text { pressure on oil prices. }\end{array}$ \\
\hline
\end{tabular}


The impact of maize-based ethanol production ...

\begin{tabular}{|l|l|}
\hline \multirow{3}{*}{ Macro economy } & $\begin{array}{l}\text { Whereas the Chinese economy will grow, but at a decreasing rate, the } \\
\text { Indian economy will grow at an increasing rate }\end{array}$ \\
\hline & $\begin{array}{l}\text { Strong growth in local economy will support the Rand and attract more } \\
\text { direct foreign investment. }\end{array}$ \\
\cline { 2 - 3 } & Gold prices remain high. \\
\cline { 2 - 3 } & US economy under pressure while Japan recovers. \\
\cline { 2 - 3 } & EU economic recovery not as fast as hoped for. \\
\hline
\end{tabular}

Table 2: Uncertainties of base scenario (2007-2015)

\begin{tabular}{|l|l|}
\hline Driver (category) & Uncertainties \\
\hline \multirow{5}{*}{ Biofuels } & Will licensing for the production of biofuels be implemented? \\
\cline { 2 - 2 } & $\begin{array}{l}\text { SASOL plant of } 600000 \text { tons of soya beans to produce } 400 \text { o00 tons } \\
\text { of cake and } 200000 \text { tons of oil. }\end{array}$ \\
\cline { 2 - 2 } & Will all the feedstock for biofuels be sou rced locally? \\
\cline { 2 - 2 } & $\begin{array}{l}\text { Government strategy on blending rates, tax incentives and subsidies, } \\
\text { tariffs on imported biofuel and the price formulation of biofuel. }\end{array}$ \\
\hline \multirow{2}{*}{ Legislation } & Political instability of ANC vs SACP/Cosatu. \\
\cline { 2 - 2 } & $\begin{array}{l}\text { Social policies of a "Welfare State" - grants and food stamps that can } \\
\text { increase the demand for protein. }\end{array}$ \\
\hline Crude oil & The discovery of an alternative source for crude oil. \\
\hline $\begin{array}{l}\text { Lack of electrical } \\
\text { supply }\end{array}$ & Decrease in production \\
\hline $\begin{array}{l}\text { Macro economic } \\
\text { shocks - USA, EU, } \\
\text { China, Japan }\end{array}$ & $\begin{array}{l}\text { Shocks occur such as a dramatic downturn in markets, world economic } \\
\text { trends would change due to high energy prices and high interest rates. }\end{array}$ \\
\hline
\end{tabular}

\subsection{APR model: Scenario $1^{6}$}

To quantify the raw material substitution with DDGS included as a raw material, the APR model developed by Briendenhann (2001) is used. This model is a linear programming feed formulation model that minimises the total cost of animal feed rations in South Africa, given the availability of raw materials and their corresponding prices. The model is divided into three regions - namely, Cape, Interior and KwaZulu-Natal. The demand for animal feeds is taken into account by the model, and the number of animals that need to be fed based on the nutrient requirements of those animals and their feed conversion ratios is determined. Imports and exports of raw materials are further determined by domestic availabilities of raw materials (Briedenhann 2001). The APR model calculates the total national animal feed demand based on the South African and the national 
human per capita consumption of animal products given the biological performance data of the animal species involved. "The model also calculates the total raw material requirements per species using linear programming and considering the animal-feed demand, raw material availability and prices" (Briedenhann 2001).

\subsection{Scenario 2}

Once scenario 1 is simulated in the BFAP and APR models, a scenario is created with two variables - namely, the blending ratios and the crude oil price. The same methodology is used as in the base scenario, where the BFAP model is used to simulate equilibrium price projections for 2015 , which are then simulated into the APR model, which is then used to generate the final results. The results from the second scenario are compared with the baseline scenario to determine the impact of high oil prices and different blending ratios on the animal-feed industry. The blending ratios proposed by the draft strategy of 2006 were $\mathrm{B}_{5}^{7}$ and $\mathrm{E}_{10}{ }^{8}$; whereas in scenario $1, \mathrm{E}_{2}$ and $\mathrm{B}_{1}$ are used because of uncertainties surrounding the strategy With the sensitivity analysis, the blending ratios are adjusted to the blending ratios proposed by the 2007 strategy, which are $\mathrm{B}_{2}$ and $\mathrm{E}_{8}$ The crude oil price increased dramatically from 2007 until mid-2008. To quantify the sensitivity of these variables, new blending ratios and a higher crude oil price are inserted into the BFAP model.

\section{The variables were adjusted in the scenario as follows:}

- The ethanol blending ratios changed from $\mathrm{E}_{2}$ to $\mathrm{E}_{8}$ for 2015 .

- The biodiesel blending ratios changed from $\mathrm{B}_{1}$ to $\mathrm{B}_{2}$ for 2015 .

- The crude oil price changed from $\$ 80$ to $\$ 145$ per barrel for 2015 .

In order to evaluate the impact of ethanol production, an additional combination is added to scenarios 1 and 2 . This additional scenario has the same drivers and uncertainties as the previous scenarios, with the only difference being the exclusion of ethanol production and therefore, the scenarios consist of the following:

1. Scenario 1 (scenario 1 with ethanol production in place)

2. Scenario 2 (scenario 2 with ethanol production in place)

3. Scenario 1 wo (scenario 1 without ethanol production)

4. Scenario 2 wo (scenario 2 without ethanol production)

The scenarios are explained graphically in Figure 1. 


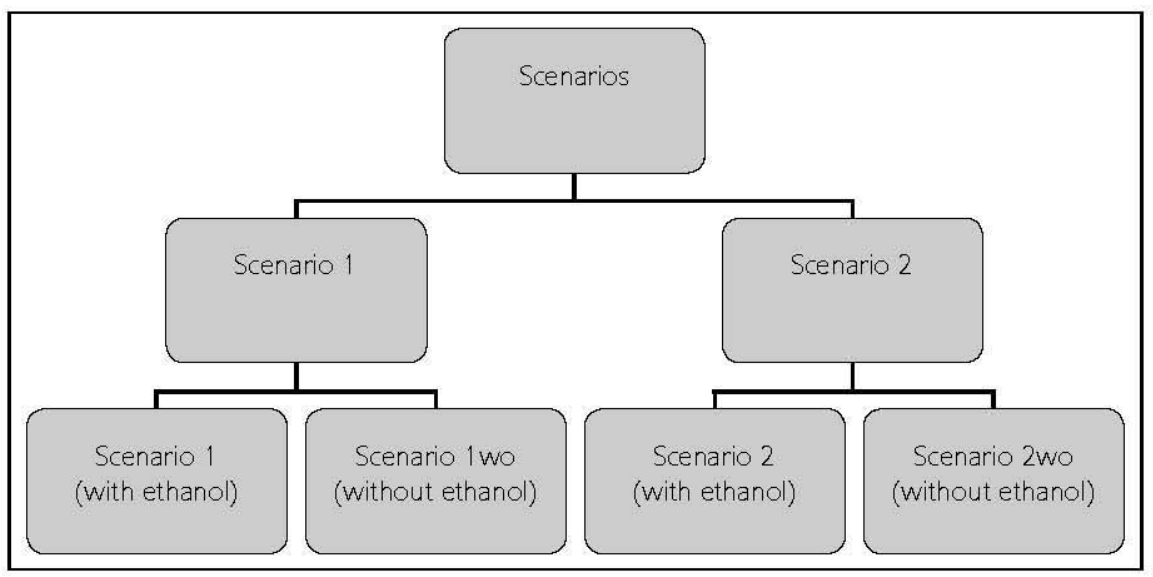

Figure 1: Graphical explanation of scenario 1 and scenario 2

\subsection{Data used}

The data used in the models contribute in an important way to the methodology, mainly in terms of the interaction between the models. This section explains all the relevant data and how the data is incorporated in the two models.

\subsubsection{BFAP data}

To simulate the equilibrium prices and forecasts with the BFAP model, a baseline data set is used for the 2006/2007 year (i.e., April 2006 to March 2007) based on the AFMA chairman's report (AFMA 2007). The AFMA year is used, because all the relevant data used in the base year of the APR model is found in this report. This data is used as a baseline to simulate the scenario and to generate price projections for the year 2015. Table 3 reflects some of the important raw material prices used as a baseline in the BFAP model, as well as base factors such as population figures, exchanges rates and the per capita consumption of products. The prices and the base data used for the BFAP baseline are illustrated in Table A1 in the annexure. 
Table 3: Raw material prices and base factors used for 2007

\begin{tabular}{|l|r|r|}
\hline Description & Unit & Value \\
\hline Raw materials & R/ton & 1000 \\
\hline Maize germ & R/ton & 2275 \\
\hline Full-fat soya & R/ton & 1650 \\
\hline Barley & R/ton & 1261 \\
\hline Maize, yellow & R/ton & 1000 \\
\hline Sorghum & R/ton & 2080 \\
\hline Soya hipro oilcake & R/ton & 1350 \\
\hline Sunflower hipro oilcake & $\mathrm{kg} /$ person & 25.39 \\
\hline Base factors & $\mathrm{kg} /$ person & 16.13 \\
\hline Per capita consumption chicken & $\mathrm{kg} /$ person & 44 \\
\hline Per capita consumption beef & $\mathrm{kg} /$ person & 6.99 \\
\hline Per capita consumption milk & $\mathrm{kg} /$ person & 3.78 \\
\hline Per capita consumption eggs & $\mathrm{kg} /$ person & 3.22 \\
\hline Per capita consumption pork & Millions & 47.38 \\
\hline Per capita consumption mutton & Rand to US $\$$ & 7.16 \\
\hline Population & & \\
\hline Exchange rate & & \\
\hline
\end{tabular}

Source: AFMA (2007) and own calculations

The equilibrium prices used in the APR model as input prices are simulated by the BFAP model in the scenario described above. The different raw material prices used in the APR model for the year 2015 are simulated with the BFAP model. A more detailed list of all the data used in the APR model is reflected in Annexure A2. These prices are in a state of equilibrium for 2015 after the inclusion of DDGS within the industry. In order to quantify the changes with the APR model, several base factors such as population and the exchange rate must be taken into consideration. These base factors are also predicted with the BFAP model.

An important variable is transport costs, mainly due to high petroleum prices and local produced raw materials versus imported materials. Table 4 reflects these transport costs used for the year 2015. The prices are calculated with the help of the $\$ /$ barrel projected by the BFAP model. For scenario 1 a crude oil price of $\$ 80 /$ barrel is simulated by the BFAP model, while for scenario 2 a crude oil price of $\$ 145 /$ barrel is simulated. This means that the transport costs from the Interior to the Cape will increase from R750 to R1275 per ton, which is a 70 per cent increase in transport costs. The transport costs are important mainly because they have an 
effect on the competitiveness of local and imported protein feed, since DDGS will be produced in the Interior.

Table 4: Transport costs for 2015

\begin{tabular}{|l|l|r|r|r|}
\hline \multirow{2}{*}{ Region } & \multirow{2}{*}{ Destination } & Base & Scenario 1 & Scenario2 \\
\cline { 3 - 5 } & & \multicolumn{3}{|c|}{ R/ton } \\
\hline Cape, KwaZulu-Natal, Interior & Within region & 160 & 200 & 340 \\
\hline Interior & Cape & 610 & 750 & 1275 \\
\hline Cape & KwaZulu-Natal & 775 & 950 & 1615 \\
\hline KwaZulu-Natal & Interior & 310 & 380 & 645 \\
\hline
\end{tabular}

The APR model did not originally include DDGS as a primary raw material and therefore, the nutritional data of DDGS are inserted into the model to overcome this constraint. The nutritional data incorporated into the model are sourced from Dunn (2005) and are reflected in Table 5 below.

Table 5: Nutrient content of DDGS

\begin{tabular}{|l|r|r|}
\hline Raw material & Amount & Unit \\
\hline Protein & 27 & $\%$ \\
\hline Fat & 9 & $\%$ \\
\hline Fibre & 9.1 & $\%$ \\
\hline DE Pigs & 16.32 & $\mathrm{mj} / \mathrm{kg}$ \\
\hline TDN & 80 & $\%$ \\
\hline ME Poultry & 10.6 & $\mathrm{mj} / \mathrm{kg}$ \\
\hline Meth Total & 0.6 & $\%$ \\
\hline Meth Avl Poultry & 0.4 & $\%$ \\
\hline TSAA Total & 0.6 & $\%$ \\
\hline TSAA Avl Poultry & 0.75 & $\%$ \\
\hline Lysine Total & 0.75 & $\%$ \\
\hline Lysine Avl Poultry & 0.5 & $\%$ \\
\hline Na & 0.48 & $\%$ \\
\hline Ca & 0.17 & $\%$ \\
\hline P Total & 0.72 & $\%$ \\
\hline P Avl & 0.65 & $\%$ \\
\hline
\end{tabular}

Source: Dunn (2005) 


\section{RESULTS \\ 4.1 Raw material equilibrium prices and macro-economic factors for 2015 - BFAP model}

With the BFAP model various raw material prices are simulated for 2015 . These prices are simulated under the different scenarios that were mentioned earlier: scenario 1 ('with' ethanol production) and scenario 1wo ('without' ethanol production). The next scenarios are scenario 2 ('with' ethanol production), where the crude oil prices and the blending ratios increase, and scenario 2wo ('without' ethanol production). Keep in mind that scenarios 1 has low blending ratios and low oil prices, whereas scenario 2 has high blending ratios and high oil prices. Because the income data and racial data will have no effect on prices, they are not used within the BFAP model.

\subsubsection{Scenario 1 and scenario 1 wo}

Scenario 1, which includes ethanol production, simulates the prices of the raw materials DDGS, soya hi pro, sunflower hi pro and full-fat soya at R1609, R3708, R3056 and R3254 respectively. The remaining prices, as well as the import prices for this specific scenario, are illustrated in Table 6. In scenario 1wo, where there is no ethanol production, the simulated prices for soya hi pro, sunflower hi pro and full-fat soya are $\mathrm{R} 3708, \mathrm{R} 3070$ and $\mathrm{R} 3256$ respectively. If the two scenarios are compared in Table 6 , the effect of ethanol production on raw material prices can be seen, since because of the ceteris paribus effect the only difference is the ethanol production. The price of yellow maize drops by 6.7 per cent from scenario 1 to scenario 1 wo, while the price of sunflower hi pro rises by 0.4 per cent. This means that ethanol production raises the price of yellow maize and lowers the price of sunflower hi pro.

\subsubsection{Scenario 2 and scenario 2wo}

In scenario 2 the raw material prices increased dramatically, mainly because of the increase in the crude oil prices that drive commodity prices upwards, as well as transport costs. Table 7 reports the prices simulated with the BFAP model for scenario 2 and scenario 2 wo. The raw material prices simulated in scenario 2 for DDGS, soya hi pro, sunflower hi pro and full-fat soya are R1954, R4303, R3346 and R4984/ton respectively. With the exclusion of ethanol production, the raw material prices simulated in scenario 2 wo for soya hi pro, sunflower hi pro and full-fat soya are R4650, R3480 and R4986/ton respectively. Comparing the scenario that includes ethanol production with the scenario that excludes ethanol production will highlight the effect of ethanol production on raw material prices 
for scenario 2 . The price of yellow maize decreases by 7 per cent from scenario 2 to scenario $2 \mathrm{wo}$, whereas the prices of sunflower hi pro and soya hi pro increases by 4 per cent and 8 per cent respectively. This means that ethanol production raises the price of yellow maize and lowers the price of sunflower hi pro and soya hi pro. The effect in scenario 2 as a whole is greater than in Scenario 1, mainly because the blending ratio increases in Scenario 2 (from 2 per cent to 8 per cent), resulting in an increase in the amount of ethanol produced.

Table 6: Predicted raw material prices for 2015 with scenario 1 and scenario 1 wo

\begin{tabular}{|c|c|c|c|c|}
\hline \multirow[t]{2}{*}{ Raw material } & \multicolumn{2}{|r|}{ Scenario 1} & \multicolumn{2}{|r|}{ Scenario 1 wo } \\
\hline & $\begin{array}{r}\text { Local price } \\
\text { (R/ton) }\end{array}$ & $\begin{array}{r}\text { Import price } \\
\text { (R/ton) }\end{array}$ & $\begin{array}{r}\text { Local price } \\
\text { (R/ton) }\end{array}$ & $\begin{array}{r}\text { Import price } \\
\text { (R/ton) }\end{array}$ \\
\hline DDGS & 1609 & & 0 & \\
\hline Fish meal hi pro & 6249 & & 6249 & \\
\hline Full-fat canola & 3531 & & 3533 & \\
\hline Full-fat soya & 3254 & & 3256 & \\
\hline Barley & 2802 & & 2802 & \\
\hline Maize, white & 1707 & 2776 & 1679 & 2776 \\
\hline Maize, yellow & 1690 & 2474 & 1577 & 2474 \\
\hline Sorghum & 1489 & & 1479 & \\
\hline Wheat & 3476 & & 3476 & \\
\hline Soya hi pro oilcake & 3708 & 3743 & 3708 & 3743 \\
\hline Sunflower hi pro oilcake & 3056 & 2922 & 3070 & 2922 \\
\hline
\end{tabular}

Table 7: Predicted raw material prices for 2015 with scenario 2 and scenario 2wo

\begin{tabular}{|c|c|c|c|c|}
\hline \multirow[t]{2}{*}{ Raw material } & \multicolumn{2}{|r|}{ Scenario 2} & \multicolumn{2}{|r|}{ Scenario 2wo } \\
\hline & $\begin{array}{r}\text { Local price } \\
\text { (R/ton) }\end{array}$ & $\begin{array}{r}\text { Import price } \\
\text { (R/ton) }\end{array}$ & $\begin{array}{r}\text { Local price } \\
\text { (R/ton) }\end{array}$ & $\begin{array}{r}\text { Import price } \\
\text { (R/ton) }\end{array}$ \\
\hline DDGS & 1954 & & - & \\
\hline Fish meal hi pro & 8372 & & 8372 & \\
\hline Full-fat canola & 5789 & & 5791 & \\
\hline Full-fat soya & 4984 & & 4986 & \\
\hline Barley & 4105 & & 4105 & \\
\hline Maize, white & 2390 & 4247 & 2349 & 4247 \\
\hline Maize, yellow & 2417 & 3772 & 2248 & 3772 \\
\hline Sorghum & 1912 & & 1898 & \\
\hline Wheat & 4857 & & 4857 & \\
\hline Soya hi pro oilcake & 4303 & 5602 & 4650 & 5602 \\
\hline Sunflower hi pro oilcake & 3346 & 3236 & 3480 & 3236 \\
\hline
\end{tabular}




\subsubsection{Macro-economic results from the BFAP model}

In the APR model, base data such as the $\mathrm{R} / \$$ exchange rate and the South African population are used. In addition to raw material prices, the BFAP model also simulates macro-economic factors such as those mentioned previously, as required by the APR model. The exchange rates in scenario 1 and 2 are R9, 82 and R10, 42 respectively, while the South African population for 2015 is given as 48.74 million for both scenarios.

\subsection{Effect of ethanol production on raw materials - APR model}

Various consumption changes within the different raw materials took place with the introduction of ethanol production and DDGS, including:

- Consumption substitution within the different raw materials

- DDGS consumption of various species

- Changes in feed costs

The APR model is used to quantify the changes in consumption of raw materials with the following scenarios:

- Scenario 1

- Scenario 1wo (without DDGS production)

- Scenario 2

- Scenario 2wo (without DDGS production)

\subsubsection{Raw material consumption substitution}

With the introduction of DDGS resulting from the production of ethanol, substitution between animal-feed raw materials takes place. Such substitution is highly dependent on the price, availability and quality of the DDGS. This section clearly illustrates all these changes for each scenario.

\subsubsection{Scenario 1}

Table 8 reflects the changes in consumption of the most important raw materials from the base year to the specific scenario along with the substitution of raw materials as a result of the introduction of DDGS. From Table 8 it can be seen that with scenario 1 the consumption of yellow maize, wheat middlings, cotton and soya hi pro increases from the base year to 2015 by 64 per cent, 50 per cent, 77 per cent and 24 percent respectively - keeping in mind that this is not the effect of ethanol production, but the effect of the scenario. This means that there is a total growth of $40.4 \%$ in consumption of raw materials from base to 2015 for scenario 
1wo. This total growth is not only for the raw materials mentioned in Table 8 , but for all the animal feed consumed in South Africa. With the exclusion of ethanol production in Scenario lwo, the consumption of yellow maize, wheat middlings, cotton and soya hi pro increases between 2007 and 2015 by 65 per cent, 50 per cent, 77 per cent and 30 per cent respectively. The total growth in animal-feed consumption from 2007 to 2015 is $3,912,176$ tons, which is a 40 per cent total growth for this period. The substitution effect between raw materials as a result of ethanol production is illustrated by means of comparing the scenarios that include DDGS and the scenarios that exclude DDGS. If Scenario 1wo and Scenario 1 are compared, the following substitutions take place:

- Sunflower hi pro and fish meal consumption increases by 1 per cent

- Soya hi pro and lucerne consumption decreases by 6 per cent and 14 per cent respectively

\subsubsection{Scenario 2}

The total DDGS production increases in scenario 1, mainly because of the increase in blending ratios. Table 9 reflects that in scenario 2 a total of 281,546 tons of DDGS is produced, while all of the tons produced are consumed as animal feed in both scenarios. With scenario $2 \mathrm{w}$, the consumption of various raw materials increases from 2007 to 2015 . The consumption of raw materials such as yellow maize, cotton and sunflower hi pro increases by 64 per cent, 78 per cent and 75 per cent respectively, while the consumption of lucerne decreases by 68 per cent. The total growth in animal feed consumption from the base year up to 2015 is 43 per cent. In scenario $2 \mathrm{wo}$, where ethanol production is excluded, the consumption of yellow maize, cotton and sunflower hi pro as animal feed increases by 70 per cent, 77 per cent and 78 per cent respectively from the base year up to 2015 . Lucerne consumption showed the opposite trend and decreased by 48 per cent, while total animal feed growth is 43 per cent. If scenario 2 wo and Scenario $2 \mathrm{w}$ are compared, the substitution effect as a result of ethanol production can be seen. With the introduction of DDGS the substitution effects are as follows:

- Yellow maize consumption decreases by 6 per cent.

- Sunflower hi pro and fish meal consumption decreases by 3 per cent and 5 per cent respectively.

- Soya hi pro and lucerne consumption decreases by 13 per cent and 20 per cent respectively. 
Table 8: Consumption and substitution of raw materials in scenario $1 \mathrm{w}$ and scenario 1 wo

\begin{tabular}{|c|c|c|c|c|c|c|}
\hline \multirow[t]{2}{*}{ Raw material } & Base year & 1 & \multirow{2}{*}{$\begin{array}{r}\% \\
\text { change } \\
\text { from } \\
\text { base }\end{array}$} & 1wo & \multirow{2}{*}{$\begin{array}{r}\% \\
\text { change } \\
\text { from } \\
\text { base }\end{array}$} & \multirow{2}{*}{$\begin{array}{r}\% \\
\text { change } \\
\text { from } \\
1 \text { wo } \\
-1\end{array}$} \\
\hline & & tons & & Tons & & \\
\hline Maize, yellow & 4288915 & 7048949 & $64 \%$ & 7068531 & $65 \%$ & $0 \%$ \\
\hline Sorghum & 7000 & 9240 & $32 \%$ & 9240 & $32 \%$ & $0 \%$ \\
\hline Maize germ & 610400 & 763000 & $25 \%$ & 763000 & $25 \%$ & $0 \%$ \\
\hline Wheat middlings & 793898 & 1192463 & $50 \%$ & 1192463 & $50 \%$ & $0 \%$ \\
\hline Maize gluten 20 & 116756 & 154118 & $32 \%$ & 154118 & $32 \%$ & $0 \%$ \\
\hline Maize gluten 60 & 26040 & 34373 & $32 \%$ & 34373 & $32 \%$ & $0 \%$ \\
\hline Cotton & 210178 & 372902 & $77 \%$ & 372900 & $77 \%$ & $0 \%$ \\
\hline Sunflower hi pro & 351190 & 461469 & $31 \%$ & 455906 & $30 \%$ & $1 \%$ \\
\hline Soya & 255640 & 303700 & $19 \%$ & 303700 & $19 \%$ & $0 \%$ \\
\hline Fish meal & 29162 & 43355 & $49 \%$ & 42962 & $47 \%$ & $2 \%$ \\
\hline Soya hi pro & 896563 & 1113099 & $24 \%$ & 1169605 & $30 \%$ & $-6 \%$ \\
\hline Lupins & 14400 & 15000 & $4 \%$ & 15000 & $4 \%$ & $0 \%$ \\
\hline Canola & 21000 & 23000 & $10 \%$ & 23000 & $10 \%$ & $0 \%$ \\
\hline Lucerne & 400108 & 403184 & $1 \%$ & 461205 & $15 \%$ & $-14 \%$ \\
\hline $\begin{array}{l}\text { Poultry } \\
\text { by-products }\end{array}$ & 94376 & 124576 & $32 \%$ & 124576 & $32 \%$ & $0 \%$ \\
\hline Feather meal & 23553 & 26775 & $14 \%$ & 26775 & $14 \%$ & $0 \%$ \\
\hline Meat-bone meal & 8361 & 11039 & $32 \%$ & 11039 & $32 \%$ & $0 \%$ \\
\hline Blood meal & 2408 & 3604 & $50 \%$ & 3604 & $50 \%$ & $0 \%$ \\
\hline Molasses & 374278 & 482050 & $29 \%$ & 482050 & $29 \%$ & $0 \%$ \\
\hline DDGS & 0 & 127100 & & 0 & & \\
\hline TOTAL & 9667137 & 13579551 & $40 \%$ & 13579313 & $40 \%$ & $0 \%$ \\
\hline
\end{tabular}

According to G. Scholtz of the Animal, Wildlife and Grassland Sciences Department of the University of the Free State (personal conversation 2008), DDGS has above-average acid-detergent fibre (ADF) and neutral-detergent fibre (NDF) levels, and this is the main reason why DDGS substitutes for lucerne, which also has an average protein level of around 12 per cent. This means that imported protein is replaced with locally produced raw materials. 
The impact of maize-based ethanol production ...

Table 9: Consumption and substitution of raw materials in scenario $2 \mathrm{w}$ and scenario $2 \mathrm{wo}$

\begin{tabular}{|c|c|c|c|c|c|c|}
\hline \multirow[t]{2}{*}{ Raw material } & Base year & 2 & \multirow{2}{*}{$\begin{array}{r}\% \\
\text { change } \\
\text { from } \\
\text { base }\end{array}$} & 2 wo & \multirow{2}{*}{$\begin{array}{r}\% \\
\text { change } \\
\text { from } \\
\text { base }\end{array}$} & \multirow{2}{*}{$\begin{array}{r}\% \\
\text { change } \\
\text { from } \\
2 w o \\
-2\end{array}$} \\
\hline & & tons & & tons & & \\
\hline Maize, yellow & 4288915 & 7032736 & $64 \%$ & 7295429 & $70 \%$ & $-6 \%$ \\
\hline Sorghum & 7000 & 9240 & $32 \%$ & 9240 & $32 \%$ & $0 \%$ \\
\hline Maize germ & 610400 & 763000 & $25 \%$ & 763000 & $25 \%$ & $0 \%$ \\
\hline Wheat middlings & 793898 & 1192463 & $50 \%$ & 1192463 & $50 \%$ & $0 \%$ \\
\hline Maize gluten 20 & 116756 & 154118 & $32 \%$ & 154118 & $32 \%$ & $0 \%$ \\
\hline Maize gluten 60 & 26040 & 34373 & $32 \%$ & 34373 & $32 \%$ & $0 \%$ \\
\hline Cotton & 210178 & 373351 & $78 \%$ & 372902 & $77 \%$ & $1 \%$ \\
\hline Sunflower hi pro & 351190 & 615417 & $75 \%$ & 626402 & $78 \%$ & $-3 \%$ \\
\hline Soya & 255640 & 303700 & $19 \%$ & 303700 & $19 \%$ & $0 \%$ \\
\hline Fish meal & 29162 & 40297 & $38 \%$ & 41582 & $43 \%$ & $-5 \%$ \\
\hline Soya hi pro & 896563 & 1013250 & $13 \%$ & 1125934 & $26 \%$ & $-13 \%$ \\
\hline Lupins & 14400 & 15000 & $4 \%$ & 15000 & $4 \%$ & $0 \%$ \\
\hline Canola & 21000 & 23000 & $10 \%$ & 23000 & $10 \%$ & $0 \%$ \\
\hline Lucerne & 400108 & 127570 & $-68 \%$ & 206115 & $-48 \%$ & $-20 \%$ \\
\hline Poultry by-products & 94376 & 124576 & $32 \%$ & 124576 & $32 \%$ & $0 \%$ \\
\hline Feather meal & 23553 & 26775 & $14 \%$ & 26775 & $14 \%$ & $0 \%$ \\
\hline Meat-bone meal & 8361 & 11039 & $32 \%$ & 11039 & $32 \%$ & $0 \%$ \\
\hline Blood meal & 2408 & 3604 & $50 \%$ & 3604 & $50 \%$ & $0 \%$ \\
\hline Molasses & 374278 & 490101 & $31 \%$ & 489505 & $31 \%$ & \\
\hline DDGS & 0 & 281546 & & 0 & & \\
\hline TOTAL & 9667137 & 13802039 & $43 \%$ & 13869313 & $43 \%$ & $0 \%$ \\
\hline
\end{tabular}

\subsubsection{Consumption of DDGS within different species}

In scenario 1, pigs consume the most DDGS with 68,418 tons, followed by dairy cattle with 23,654 tons. The rest of the consumption figures for the different species in scenario 1 can be viewed in figure 2 . 


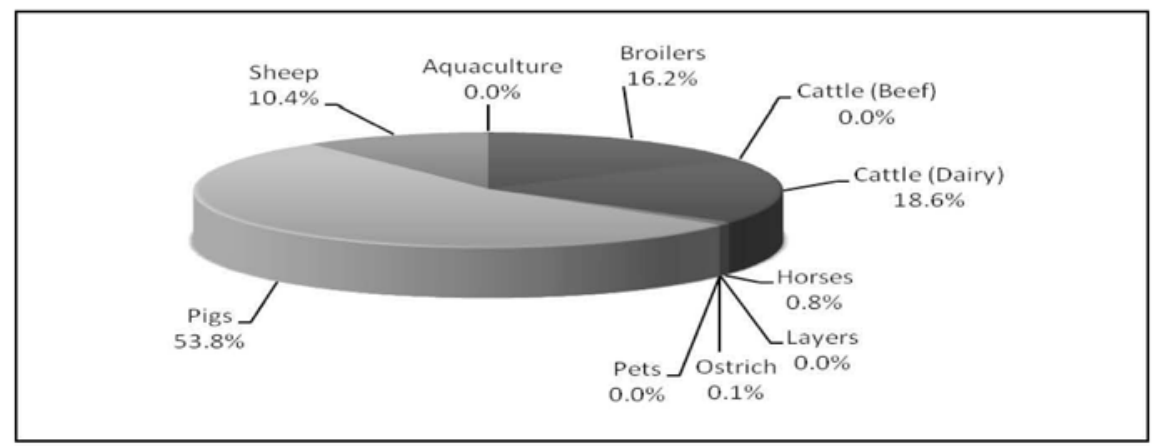

Figure 2: Consumption of DDGS by different species in scenario 1

According to Scenario 2, broilers consume the most DDGS with 170,746 tons, followed by pigs with 67,491 tons. The rest of the consumption figures for the different species in scenario 2 are shown in Figure 3.

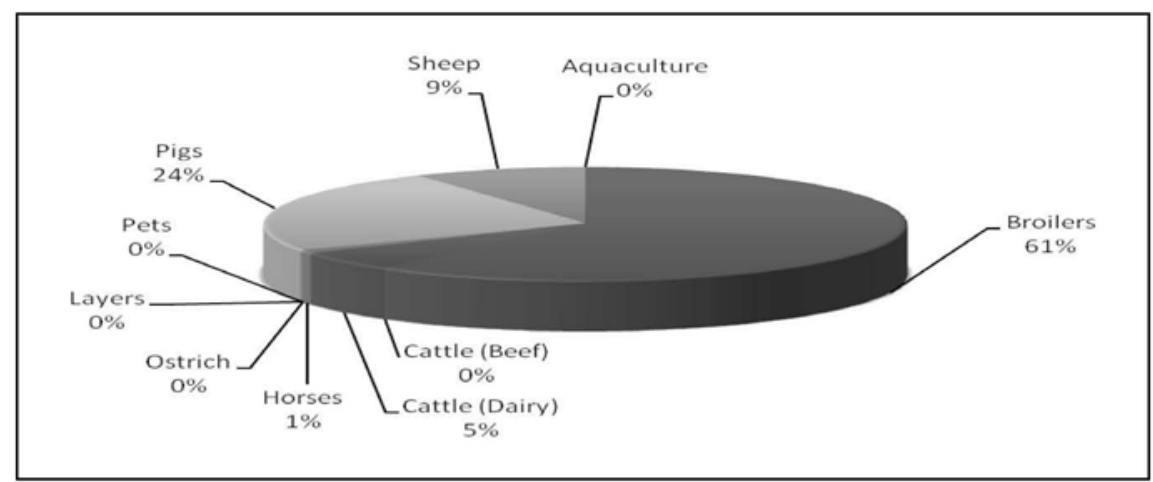

Figure 3: Consumption of DDGS by different species in scenario 2

The dominant DDGS-consuming species are pigs, broilers and dairy cattle. The consumption figures for all the different species are reflected in Table 10 below. 
Table 10: DDGS consumption per species

\begin{tabular}{|l|r|r|}
\hline \multirow{2}{*}{ Species } & Scenario 1 & Scenario 2 \\
\cline { 2 - 3 } & \multicolumn{2}{|c|}{ Tons } \\
\hline Aquaculture & 0 & 0 \\
\hline Broilers & 20584 & 170746 \\
\hline Cattle (Beef) & 0 & 0 \\
\hline Cattle (Dairy) & 23654 & 15622 \\
\hline Horses & 1044 & 2254 \\
\hline Layers & 0 & 0 \\
\hline Ostriches & 130 & 201 \\
\hline Pets & 0 & 323 \\
\hline Pigs & 68418 & 67491 \\
\hline Sheep & 13270 & 24909 \\
\hline Total & 127100 & 281546 \\
\hline
\end{tabular}

With the change in blending ratios, some of the species consumed more DDGS than other species, indicating the sensitivity to changes in DDGS availability. The species most sensitive to changes in DDGS availability are broilers, dairy cattle, pigs and sheep; this is mainly due to the sensitivity levels of micotoxin.

\subsubsection{Changes in feed costs}

The total animal feed cost increases from the base year to the scenario as follows:

- In scenario 1 , total costs increase by $35 \%$ (R 8.1 billion increase)

- In scenario 1wo, total costs increase by $37 \%$ ( $\mathrm{R} 8.5$ billion increase)

Figure 4 shows the total animal feed costs for scenario 1 . These increases mentioned above are mainly due to an increase in demand for raw materials, as well as an increase in the exchange rate together with an increase in transport costs. 


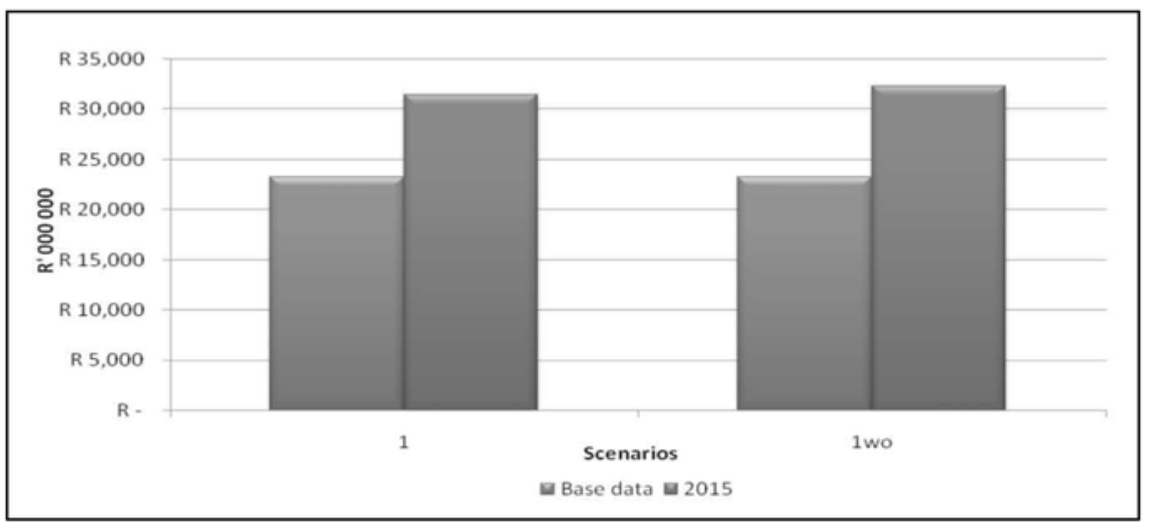

Figure 4: Total animal feed costs for scenario 1

The total animal feed costs for scenario 2 are illustrated in Figure 5 . The following changes in animal feed costs take place:

- In scenario $2 \mathrm{w}$ total costs increase by 92 per cent (R 21.4 billion increase)

- In scenario 2wo, total costs increase by 94 per cent (R 22.9 billion increase)

The increase in animal feed costs in scenario 2 is more intense than in scenario 1. In scenario 2 it is not because of a change in demand, but mostly because of a higher exchange rate combined with higher transport costs.

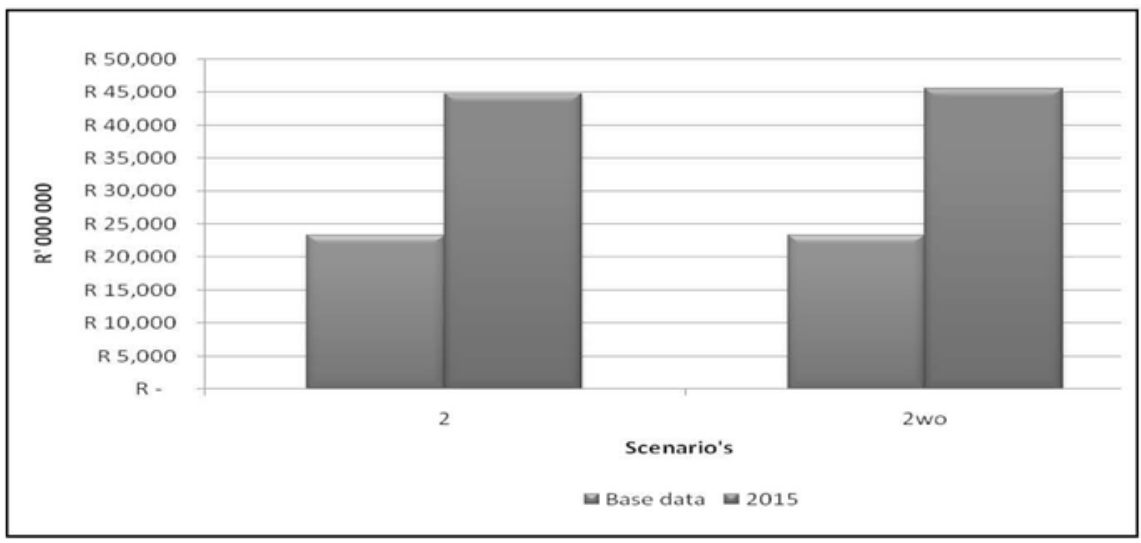

Figure 5: Total animal feed cost for Scenario 2 


\subsubsection{Effect of ethanol production on feed costs}

In scenario 1 the total animal-feed cost increases from scenario $1 \mathrm{w}$ to scenario 1 wo by 1.2 per cent, which is an increase of $R 384,221,362$. The total animal feed costs as well as the feed cost changes for the different scenarios in scenario 1 are reflected in Table 11.

Table 11: Total animal feed costs for scenario 1

\begin{tabular}{|l|r|r|r|}
\hline Cost & 1 & 1wo & $\begin{array}{r}\text { \% change from with - } \\
\text { without DDGS }\end{array}$ \\
\hline Total animal feed & $31,429,585,905$ & $31,813,807,267$ & $1.20 \%$ \\
\hline
\end{tabular}

In Scenario 2 the total animal-feed cost increases from scenario $2 \mathrm{w}$ to scenario 2 wo with $R 879,296,512$, which is an increase of 2 per cent. Table 12 reflects the total animal feed costs for scenario 2 along with the changing percentages.

Table 12: Total animal feed costs for scenario 2

\begin{tabular}{|l|r|r|r|}
\hline Cost & 2 & 2 wo & $\begin{array}{r}\text { \% change from with - } \\
\text { without DDGS }\end{array}$ \\
\hline Total animal feed & $44,667,582.019$ & $45,546,878,531$ & $2 \%$ \\
\hline
\end{tabular}

\section{CONCLUSION AND RECOMMENDATIONS}

This paper shows the impact of alternative biofuel blending ratios on the animal feed sector. A further sensitivity analysis based on higher crude oil price is also illustrated. In the scenario, 127000 tons of DDGS were introduced into the feed market, resulting from the proposed blending rates of $\mathrm{E}_{2}$ and $\mathrm{B}_{1}$. It is clear from the results that at these blending ratios, the DDGS quantity release is too small to have a big impact on the feed industry. The total animal feed cost increased, mainly because of factors such as exchange rates, raw material prices and the transport costs of raw materials that have increased strongly.

The impact of the crude oil price scenario shows an estimated increase in the total animal feed cost of 33.12 per cent given the $\mathrm{B}_{1}$ and $\mathrm{E}_{2}$ blending ratios and a crude oil price of $\$ 80 /$ barrel from 2007 up to 215 . When these variables are changed to $\mathrm{B}_{2}$ and $\mathrm{E}_{8}$ with a crude oil price of $\$ 145 /$ barrel, the animal feed cost increases with 172 per cent. With this higher availability of DDGS (281 000 tonnes), less maize, wheat middlings and soya oilcake were consumed, because of the substitute effect of these raw materials, which means that less protein is imported.

It is, therefore, clear from the analysis that a national government policy on compulsory biofuel blending rates will influence the animal feed sector in two main ways. Firstly, new raw materials, DDGS, will become available in the South 
African market, which can replace other imported protein rich raw materials such as oilcakes. It is important also to note that an increase in local biodiesel production is further likely to increase the local availability of oilcakes. Secondly, the energy usage from grain crops will most probably result in additional import requirements of raw materials, as South African is an overall net importer of grain and grain products.

With the ethanol production figures of scenario 1 and scenario 2 , there is no significant effect on the animal feed industry. The prices of raw materials change by a small percentage only. The consumption of raw material substitutes experiences the same effect as the prices of raw materials, with no significant changes taking place, with the exception of lucerne consumption, which decreases by 20 per cent. In terms of feed costs, the animal feed industry will see a 2 per cent change, and the conclusion can be drawn that ethanol production will have a minor affect on the animal feed industry in South Africa. The biggest effect will be that DDGS will replace some of the imported protein, which improves the competitiveness of the local feed producers; this in return is a positive impact in terms of the foreign exchange environment. The reason for the small cost effect is that DDGS will also be produced at a price and does not come free of charge. It can only replace expensive raw materials, and more maize is needed for ethanol production. There is also a need for more practical research to determine the effect that DDGS consumption will have on the diets of species such as broilers, swine and dairy cattle in South Africa. This means that more specific feeding test and nutritional information must be obtained for a South African scenario. The impact of possible human consumption of DDGS can also be included into the models although it is not yet a common practice worldwide.

If the biofuels industry strategy proposed by the DME is implemented, the effect on the South African animal feed industry will not be major if ethanol is produced with maize. Further research is still needed to determine the possible effect on food security, but when it comes to animal feed, ethanol production can take place without any negatives effects, provided that the quality of the DDGS is of a global standard.

\section{NOTES}

1 The authors wish to gratefully acknowledge the financial contribution of the Protein Research Foundation (PRF).

2 Post graduate student and researcher, Department of Agricultural Economics, University of the Free State, South Africa. DStrydom@ufs.ac.za

3 Senior Lecturer and member of BFAP team at the Department of Agriculture Economics, University of Pretoria, South Africa. Ferdi.meyer@up.ac.za

4 Lecturer, Department of Agricultural Economics, University of the Free State, South Africa. TaljaaPR@ufs.ac.za 
5 Professor, Department of Agricultural Economics, University of the Free State, South Africa. willemsebj@ufs.ac.za

6 The authors thank Dr Briedenhann for his valuable contribution in elucidating the APR model.

$75 \%$ blending of biodiesel into diesel nationally

$8 \quad 10 \%$ blending of ethanol into petrol nationally

\section{REFERENCES}

AFMA (Animal Feed Manufacturers' Association), 2007. Chairman's report 2006/2007. Available from http://www.afma.co.za/AFMA_Template/1,2491,544,00.html (Accessed on 10 October 2007).

Albers A, 2006. Chemin client's business master plan. Port Elizabeth: Kyle Business Projects.

Babcock, B. 2008. Three Drivers of Distributional Shifts in Domestic Agricultural Policy. Paper presented at the 2008 Allied Social Science Meeting, New Orleans, LA.

Banse, M., Van Meij1, H., Tabeau, A., and Woltjer, G. 2007. Impact of EU Biofuel Policies on World Agricultural and Food Markets. Presented at the 10th Annual Conference on Global Economic Analysis, Purdue University, USA.

Birur, D., Hertel, T. and Tyner, W. 2008. Impact of Biofuel Production on World Agricultural Markets: A Computable General Equilibrium Analysis. Forthcoming GTAP Working Paper, www.gtap.org.

Briedenhann, E. 2001. A model to predict animal feed and raw material requirements for the animal feed incustry in South Africa. Thesis (PhD). University of Natal, Pietermaritzburg.

Dixon, P., Osborne, S. and Rimmer, M. 2007. The economy-wide effects in the United States of America replacing crude petroleum with biomass, Presented at the 10th Annual Conference on Global Economic Analysis, 7-9 June 2007, Purdue University, Indiana, USA.

DME, 2007. Draft Biofuels Industrial Strategy of the Republic of South Africa. Pretoria, SouthAfrica.

Dunn, L. 2005. The value of DDGS to the formal feed industry in South-Africa. Senwesko feeds, Viljoenskroon, RSA.

Hertel, T., Tyner, W. and Birur, D. 2008. Biofuels for all? Understanding the Global Impacts of Multinational Mandates. Center for Global Trade Analysis, Department of Agricultural Economics, Purdue University.

Lemmer, W. 2006. Bio-ethanol production in the Western Cape. Cape Town: Department of Agriculture, Western Cape.

Meyer, F., Strauss, P.G. and Funke, T. 2008. Modelling the impacts of macro-economic variables on the South African biofuels industry. Agrekon, 47(3) 327-345.

Reilly, J. and Paltsev, S. 2007. Biomass Energy and Competition for Land. Presented at the 10th Annual Conference on Global Economic Analysis, Purdue University, USA.

RFA (Renewable Fuels Association). 2007. Homegrown for the homeland: Ethanol Industry Outlook 2007. Washington DC: RFA.

Shurson, J. and Noll, S. 2005. Feed and Alternative Uses for DDGS. Energy from agriculture: New techologies, Innovative programs \& Success stories, Department of Animal Science, University of Minnesota. 
Taheripour, F., Hertel, T. and Tyner, W. 2008. Biofuels and their By-Products: Global Economic and Environmental Implications. Department of Agricultural Economics, Purdue University.

Tokgoz, S., Elobeid A., Fabiosa J., Hayes D., Babcock B., Yu, F., Dong T., Hart C., and Beghin, J. 2007. Emerging biofuels: Outlook of effects on U.S. grain, oilseed, and livestock markets. Iowa State University, Dept. of Economics. Staff Report 07-SR 101.

Trenkle, A. 2005. The advantages of using com distiller's grains with solubles in finishing beef cattle diets. Ames, IA: Iowa State University.

Tyner, W. and Taheripour, F. 2008. The US biofuels market: Policy alternatives for the future. Paper presented at the 2008 Allied Social Science Meeting, 4-6 January 2008, New Orleans, Louisiana, USA.

USDA, 2007. Overview of renewable fuels. Available from http://www.usda.gov/wps/portal/ usda/!ut/p/c4/04_SB8K8xLLM9MSSzPy 8xBz9CP0os_gAC9-wMJ8QY0M DpxBDA09nXw9DFxcXQ-cAA_2CbEdFAEUOjoE!/?navtype=SU\&navid=AGRICULTU RE (Accessed on 26 September 2008).

\section{ANNEXURE}

Table A1: Most important data used in the 2007 BFAP baseline model

\begin{tabular}{|l|l|r|}
\hline Base factors & 2007 \\
\hline Base factors & Factor & 2007 \\
\hline Consumption & Base year & 2007 \\
\hline Exchange rate & Base year & 7.16 \\
\hline Exchange rate & Exchange Rate (Rand to US\$) & 2007 \\
\hline Population & Base year & 47.35 \\
\hline Population & Population (millions) & 0.54 \\
\hline Population & \% Increase per annum & Actual \\
\hline Base per capita consumed & & 25.39 \\
\hline Per capita consumption chicken & & 16.13 \\
\hline Per capita consumption cattle beef & & 44 \\
\hline Per capita consumption milk & & 6.99 \\
\hline Per capita consumption eggs & & 3.78 \\
\hline Per capita consumption pork & & 3.22 \\
\hline Per capita consumption mutton & & R/ton \\
\hline RM prices & & 6700 \\
\hline Acid oil & & 1900 \\
\hline CMS molasses & & 1000 \\
\hline Maize Germ & & 1800 \\
\hline Wheat middlings & & \\
\hline
\end{tabular}


The impact of maize-based ethanol production ..

\begin{tabular}{|c|c|c|}
\hline Maize gluten 20 & & 880 \\
\hline Maize gluten 60 & & 3000 \\
\hline Fish meal hi pro & & 6200 \\
\hline Full-fat canola & & 2900 \\
\hline Full-fat cotton & & 1800 \\
\hline Full-fat soya & & 2275 \\
\hline Barley & & 1650 \\
\hline Maize white & & 1289 \\
\hline Maize yellow & & 1260.97 \\
\hline Oats & & 1400 \\
\hline Sorghum (KZN) & & 1350 \\
\hline Canola oilcake & & 1340 \\
\hline Soya hi pro oilcake & & 2080 \\
\hline Sunflower hi pro oilcake & & 1350 \\
\hline Lucerne & & 1500 \\
\hline Milk replacers & & 6000 \\
\hline Roughage & & 2000 \\
\hline Blood meal & & 3000 \\
\hline Feather meal & & 3000 \\
\hline Meat-bone meal & & 2400 \\
\hline Poultry byprod & & 3200 \\
\hline RM transport cost & Destination & $\mathrm{R} /$ ton \\
\hline Cape & Cape & 160 \\
\hline Cape & Interior & 610 \\
\hline Cape & $\mathrm{KZZN}$ & 775 \\
\hline Interior & Cape & 610 \\
\hline Interior & Interior & 160 \\
\hline Interior & $K Z N$ & 310 \\
\hline $\mathrm{KZN}$ & Cape & 775 \\
\hline KZN & Interior & 310 \\
\hline KZN & KZN & 160 \\
\hline
\end{tabular}

Sources: AFMA (2007) and Briedenhann (2001) 
D.B. Strydom, F. Meyer, P.R. Taljaard and B.J. Willemse

Table A2: Base factors for APR model

\begin{tabular}{|l|l|r|}
\hline APR base year data & 2007 \\
\hline Base factors & Factor & 2007 \\
\hline Consumption & Base year & 2007 \\
\hline Exchange rate & Base year & 7.16 \\
\hline Exchange rate & Exchange Rate (Rand to US\$) & 0 \\
\hline Exchange rate & \% Increase per annum & 2007 \\
\hline Population & Base year & 47.35 \\
\hline Population & Population (millions) & 0.54 \\
\hline Population & \% Increase per annum & Kg/person \\
\hline Base per capita consumed & & 25.39 \\
\hline Per capita consumption chicken & & 16.13 \\
\hline Per capita consumption cattle beef & & 44 \\
\hline Per capita consumption milk & & 6.99 \\
\hline Per capita consumption eggs & & 3.78 \\
\hline Per capita consumption pork & & 3.22 \\
\hline Per capita consumption mutton & & \\
\hline
\end{tabular}

